\title{
Isolation and Characterization of Ralstonia solanacearum Causing Bacterial Wilt of Solanaceae Crops
}

\author{
Sujeet Kumar $^{1}{ }^{*}$ Kedarnath $^{2}$, N. Hamsaveni ${ }^{1}$, P.H. Ramanjini Gowda ${ }^{1}$ \\ I.B. Rohini ${ }^{1}$, K.T. Rangaswamy ${ }^{2}$ and Raghavendra Achari ${ }^{2}$ \\ ${ }^{1}$ Department of Plant Biotechnology and ${ }^{2}$ Department of Plant Pathology, University of \\ Agricultural Sciences, GKVK, Bengaluru-560065, India \\ *Corresponding author email id:
}

\begin{tabular}{|c|c|}
\hline & A B S T R A C T \\
\hline & Bacterial wilt caused by Ralstonia solanacearum is the most destructive disease of crop \\
\hline Keywords & lycopersicum) and brinjal (S. melongena) were collected from different locations of \\
\hline $\begin{array}{l}\text { Ralstonia } \\
\text { solanacearum, } \\
\text { Bacterial wilt, } \\
\text { Tomato, } \\
\text { Phylotype, Biovar. }\end{array}$ & $\begin{array}{l}\text { Karnataka, India. All the six isolates were identified as } R \text {. solanacearum by colonies } \\
\text { phenotype, simple staining, streaming and } R \text {. solanacearum species specific PCR. In this } \\
\text { study, six isolates were differentiated into race on the basis of their ability to infect } \\
\text { different host. The isolates- } 1,2,4 \text { and } 5 \text { were established as race- } 3 \text { and isolates- } 3 \text { and } 6 \\
\text { were established as race- } 1 \text {. Biovar characterization was performed by their ability to utilize }\end{array}$ \\
\hline Article Info & sorbitol and dulcitol (Himedia)]. According to Hayward's classification system, the \\
\hline $\begin{array}{l}\text { Accepted: } \\
12 \text { April } 2017 \\
\text { Available Online: } \\
10 \text { May } 2017\end{array}$ & $\begin{array}{l}\text { isolates-1, } 2,4 \text { and } 5 \text { were belongs to biovars- } 2 \text { and isolates- } 3 \text { and } 6 \text { were belongs to } \\
\text { biovars- } 3 \text {. Molecular analysis, including multiplex PCR-based phylotyping and sequence } \\
\text { analysis of } 16 \mathrm{~s} \text { rDNA were used to determine the ITS sequences of six } R \text {. solanacearum } \\
\text { strains. The results of Pmx-PCR for all six isolates revealed that all isolates are belonged } \\
\text { to phylotype I. Therefore it mav be confirmed that } R \text { solanacearum causing bacterial wilt }\end{array}$ \\
\hline & of tomato and brinjal in Karnataka belong to Biovar-2, 3 and Race 1, 3 and phylotype I. \\
\hline
\end{tabular}

\section{Introduction}

Bacterial wilt pathogen Ralstonia solanacearum (Smith, 1896; Yabuuchi et al., $1995)$ is a gram negative, rod shaped, $\beta$ proteobacteria, nonsporulating, aerobic, soilborne, motile bacterium with a polar tuft of flagellum. It causes wilt diseases in plants by invading through xylem vessels (Genin, 2010). It colonizes the root surface and then invades xylem vessels by degrading cell wall and produces ample quantities of exopolysaccharides which in turn blocks water flow causing chlorosis, wilting of plants and eventually plant death. Its ability to persist in soil and infesting plant parts adds to the difficulty in elimination of inocula (Genin and Denny, 2012). It occurs widely in tropical, subtropical and warm temperate parts of the globe (Liu et al., 2009) and causes catastrophic yield loss in major crops like tomato, eggplant, potato, tobacco, pepper, banana, peanut, ginger, etc. (Peeters et al., 2013). It has a powerful and tissue specific tropism in host plants, specifically invading and rapidly multiplying in the xylem vessels. 
It has an extensive host range of $\sim 450$ crop species (Swanson et al., 2005) across 54 families (Wicker et al., 2007). There is huge genetic diversity in $R$. solanacearum (formerly Pseudomonas solanacearum, Yabuuchi et al., 1995) across the globe and thus it is termed as $R$. solanacearum species complex (RSSC). These marked differences in geographical distribution suggest separate evolutionary development. The variability in $R$. solanacearum species complex is classified by different workers on the basis of different criteria like host range, utilization of different carbon sources, phylogenetic relationship, etc. (OEPP 2004).

The race, biovar and phylotype classification has gained wide acceptance for subdividing $R$. solanacearum species complex. The racial pattern system groups the strains of $R$. solanacearum according to their ability to infect different host plants, viz., race 1 comprised of many strains having a wide host range and pathogenic on different solanaceous plants and weed hosts, race 2 is restricted to triploid banana and Heliconia, race 3 (potato race) affects potato, race 4 infects ginger, and race 5 is pathogenic on mulberry (Buddenhagen et al., 1962; Aragaki and Quinon, 1965; He et al., 1983; Begum, 2005; Rahman et al., 2010; Chandrashekara et al., 2012, Popoola et al., 2015). Five races are also different in geographical distribution and ability to survive under different environmental conditions (French, 1986). $R$. solanacearum was grouped into four biovars on the basis of utilizing and/or oxidizing three hexoses (mannitol, dulcitol and sorbitol) and three disaccharides (lactose, maltose and cellobiose) (Hayward, 1954; He et al., 1983; Begum, 2005; Rahman et al., 2010; Chandrashekara et al., 2012, Popoola et al., 2015).

Fegan and Prior (2005) developed a new hierarchical classification scheme by analysis of the internal transcribed spacer (ITS) region, the endoglucanase (egl) gene and the hrpB gene. A phylotype-specific multiplex PCR (Pmx-PCR) was employed in this scheme to distinguish four phylotypes (I, II, III, IV). A number of different phenotypic and genotypic methods are presently being employed for the identification and classification of bacteria, including plant pathogenic bacteria like Ralstonia. Each of these methods permits a certain level of phylogenetic classification from the genus, species, subspecies, biovar to the strain level. Moreover, each method has its advantages and disadvantages with regard to ease of application, reproducibility, requirement for equipment and level of resolution. Modern phylogenetic classification is based on 16S rRNA sequence analysis (Cook et al., 1989; Gillings et al., 1993; Seal et al., 1992; Seal et al., 1993; Poussier et al., 2000; Popoola et al., 2015)

There exists a lot of controversy regarding the prevalence of strains in the various parts of the world. In India, however, scant information is available about the prevalence of biovars/races and strains in various parts of the country. Understanding local pathogen genetic diversity is the first step in a successful breeding and integrated disease management programme. One of the purposes of the present investigation on six isolates of $R$. solanacearum causing wilt on tomato and brinjal isolated from different agro-climatic zones of Karnataka is to characterize then into races, biovars and phylotype.

\section{Materials and Methods}

\section{Isolation and characterization of Ralstonia solanacearum}

\section{Collection of sample}

Plant and soil samples were collected for isolation of $R$. solanacearum from diverse 
sites around Karnataka, India (Table 1). The presence of pathogen was tested by placing longitudinal sections of the collar portion containing vascular tissues from diseased plants in a test tube containing clean water. The infected tissues shows fine milky white strands composed of masses of bacteria, which oozes out from the margin of the cut portion within few minutes.

\section{Isolation of Ralstonia solanacearum}

The bacterial wilt disease confirmed tissue was used for isolation. The outer parts of infected material were removed with a sterilized scalpel.

The small pieces were placed in distilled water for 10 to 15 minutes. The inoculation loop was dipped in the ooze and streaked on Triphenyltetrazolium Chloride (TZC) (Himedia) media. [TZC media was $10 \mathrm{~g}$ peptone, $1 \mathrm{~g}$ casein hydrolysate, $10 \mathrm{~g}$ dextrose, $18 \mathrm{~g}$ agar and $5 \mathrm{ml}$ of 1 per cent triphenyltetrazolium chloride (TZC) for one litre of distilled water].

The streaked plates were incubated at $28 \pm 1^{\circ} \mathrm{C}$ for 24 to 48 hours. The virulent (pink color at the centre with fluidal in nature) colonies were isolated and then suspended in sterilized distilled water in screw capped vials and stored at room temperature. They were regularly renewed and checked for virulence by plating on TZC medium.

\section{Identification of virulent and avirulent isolates}

The virulent (colonies with pink or light red color or characteristic red center and whitish margin) and avirulent (smaller, brick red and non-fluidal colonies) strains of $R$. solanacearum were identified in TZC medium containing $0.005 \%$ TZC (Kelman, 1954).

\section{Characterization of the pathogen}

Different biochemical tests were performed to characterize the $R$. solanacearum are described below.

\section{Gram staining}

A loop full of the bacterium was spread on a glass slide and fixed by heating on a very low flame. Aqueous crystal violet (Himedia) solution $(0.5 \%)$ was spread over the smear for 30 seconds and then gently washed with slow running tap water for one minute. It was then flooded with iodine for one minute, rinsed in tap water and decolorized with $95 \%$ ethanol until colorless runoff. After washing, the specimen was counter-stained with safranin (Himedia) for approximately 10 seconds, washed with water, dried and observed under microscope at $40 \mathrm{X}$ using immersion oil (Schaad, 1980).

\section{Streaming test}

A presumptive test was carried out on infected tomato plant to diagnose the presence of $R$. solanacearum. Stems of infected tomato plants were cut above the soil level and the cut surfaces were suspended in test tube containing clean water.

\section{Host range studies and race determination}

Races were assigned based on host range (Buddenhagen et al., 1962; Schaad et al., 2001). Studies on four species in the family Solanaceae (tomato-Solanum lycopersicum, chilli-Capsicum annuum, brinjal-Solanum melangena and potato- $S$. tuberosum) and one in Moracea family (Mulbery-Morus alba L.) (Table 3) were used. The one month old seedlings were inoculated with $R$. solanacearum by trimming the roots and dipping in bacterial suspension for 30 minutes (Klement et al., 1990). The inoculated plants 
were then kept in net house until the symptoms were developed. $R$. solanacearum from the wilted plant was reisolated on TZC agar and colonies were compared with the original culture.

\section{Determination of biovars}

The isolates of $R$. solanacearum were differentiated into biovars based on their ability to utilize disaccharides [Sucrose, lactose, and maltose (Himedia)] and sugar alcohols [mannitol, sorbitol and dulcitol (Himedia)] (Table 4) as described previously by Hayward (1954) and He et al., (1983). The biovars were determined in the mineral medium (Himedia) $\left(\mathrm{NH}_{4} \mathrm{H}_{2} \mathrm{PO}_{4} 1.0 \mathrm{~g}, \mathrm{KCl}\right.$ $0.2 \mathrm{~g}, \mathrm{MgSO}_{4} .7 \mathrm{H}_{2} \mathrm{O} 0.2 \mathrm{~g}$, Difcobacto peptone $1.0 \mathrm{~g}$, Agar $3.0 \mathrm{~g}$ and Bromothymol blue 80.0 mg per litre) containing 1\% sugar. About 200 $\mu l$ of the melted medium is dispensed into the wells of microtitre plate. Inocula for each group of isolates was prepared by adding several loopful of bacteria from $24-48 \mathrm{~h}$ old cultures to distilled water to make suspension containing about $10^{8} \mathrm{CFU} / \mathrm{ml}$. Then $20 \mu \mathrm{l}$ of bacterial suspension was added to the wells of microtitre plate and incubated at $28-32^{\circ} \mathrm{C}$. The tubes were then examined at 3 days after inoculation for change in $\mathrm{pH}$ by color change (Schaad et al., 2001).

\section{Molecular characterization of Ralstonia solanacearum}

\section{Genomic DNA extraction and purification}

Genomic DNA isolation was performed by Amnion bacterial g DNA isolation protocol.

Ralstonia solanacearum confirmed by Polymerase chain reaction (PCR) amplification

All six isolates were PCR amplified using two sets of primers corresponding to $16 \mathrm{~S}$ rDNA (OLI1 and Y2) and 16S rRNA (Y1 and Y2), as described by Seal et al., 1993 (Table 5). PCR products were resolved on $1.2 \%$ agrose gel.

\section{Phylotype determination}

A phylotype-specific multiplex PCR (PmxPCR) was performed to determine the phylotype affiliation of all strains (Fegan and Prior, 2005). A set of four phylotype-specific forward primers (Nmult:21:1F, Nmult:21:2F, Nmult:23:AF, Nmult:22:InF, and Nmult:22:RR) with a unique and conserved reverse primer (Nmult:22:RR) targeted in the $16 \mathrm{~S}-23 \mathrm{~S}$ intergenic spacer region (internal transcribed spacer) were used for the study (Table 6). The mixture contained $12.5 \mu \mathrm{l}$ of $2 \times \mathrm{PCR}$ buffer, $0.6 \mu \mathrm{l}$ of each forward primer $(10 \mu \mathrm{mol} / 1), 2.4 \mu \mathrm{l}$ of reverse primer (Nmult:22:RR), $0.4 \mu \mathrm{l}$ of $759 \mathrm{R}$ and $760 \mathrm{~F}$ primers and $2 \mu \mathrm{l}$ template mix (about 50 $\mathrm{ng} / \mu \mathrm{l})$. The final volume was made up to 25 $\mu l$ using PCR-grade water. The PCR reaction was prepared and subjected to thermocycling at the following temperatures: $94^{\circ} \mathrm{C}$ for $15 \mathrm{~s}$, $59^{\circ} \mathrm{C}$ for $30 \mathrm{~s}$, and $72^{\circ} \mathrm{C}$ for $30 \mathrm{~s}$ and a final extension of $72^{\circ} \mathrm{C}$ for $10 \mathrm{~min}$. PCR products were resolved using agarose $1.5 \%$ (wt/vol) gel electrophoresis. Amplicon sizes were estimated by comparison to a 100-bp DNA ladder. This Pmx-PCR produces the following phylotype specific PCR products: a 144-bp amplicon from phylotype I strains, a 372-bp amplicon from phylotype II strains, a 91-bp amplicon from phylotype III strains, and a 213-bp amplicon from phylotype IV strains.

\section{Results and Discussion}

Isolation and characterization of isolates of $\boldsymbol{R}$. solanacearum from Karnataka

The six isolates were isolated from infected plant sample and characterized by morphological, biochemical and molecular methods. 
The result of this objective described in the following subheading.

\section{Confirmation for $\boldsymbol{R}$. solanacearum}

Six wilt causing bacterial isolates were identified as $R$. solanacearum based on their typical fluidal, irregular colony morphology with a characteristic spiral pink centre on TZC agar amended with 2,3,5-teiphenyl tetrazolium chloride (Fig. 1). The isolates represented geographically distinct locations such as Gandhi Krishi Vignyan Kendra, Indian Institute of Horticulture Research Hesaraghatta, Main Agricultural research station Hebbal and Sadahalli farm Devanahalli Bengaluru, Karnataka.

\section{Assessment of cfu of isolates of Ralstonia solanacearum at different locations}

The number of colony forming unit (cfu) were assessed at different dilutions of isolates of $R$. solanacearum (Table 2 and Fig. 3). In all isolates, the cfu were uncountable at zero dilution. At first dilution $\left(10^{-1}\right)$ the cfu were uncountable in isolate- $2,4,5$ and 6 , while cfu were recorded 120 and 180 in isolate- 1 and 3 , respectively. At second dilution $\left(10^{-2}\right)$, the isolates $^{-5}$ and 6 were uncountable whereas isolate-1, 2, 3 and 4recorded 41, 80, 90 and 150 respectively. The maximum cfu were recorded in isolate-2(75), isolate-6(61), isolate-6(45) and isolate-3(28) whereas minimum cfu was recorded in isolate-1 i.e. 29,33 and 0 at $10^{-3}, 10^{-4}, 10^{-5}$, and $10^{-6}$ dilutions, respectively

\section{Identification of virulent/avirulent strains of $R$. solanacearum}

All isolates of $R$. solanacearum collected from different growing areas produced pink or light red coloured colonies with characteristic red centre and whitish margin on TZC medium (Fig. 2). It indicates that, all the isolates were belongs to virulent.

\section{Host range studies and race determination}

The races of $R$. solanacearum were identified by pathogenicity test on wide host ranges (tomato, chilli, potato, mulberry, brinjal and banana). The results of pathogenicity test revealed that, the isolate- 1 , isolate- 2 , isolate- 4 and isolate-5 showed wilting symptoms only in solanaceous families (tomato, chilli, potato and brinjal) not in other crops, hence it was identified as race-3 whereas isolate- 3 and isolate-6 showed wilting symptom in solanaceous families (tomato, chilli, potato and brinjal). The banana was also identified as race-1 (Table 3 and Fig. 5, 6, 7 and 8).

\section{Streaming test}

A presumptive test was carried out on infected tomato plant to diagnose the presence of $R$. solanacearum. Stems of infected tomato plants were cut above the soil level and the cut surfaces were suspended in beaker containing millipore water and it appeared as cloudiness streaming down (Fig. 8).

\section{Biochemical tests}

Biochemically $R$. solanacearum was confirmed by gram staining and Biovar differentiation test.

\section{Gram staining}

Bacterial staining reddish pink color indicates that these bacteria are gram-negative (G-ve), All six isolates exhibited reddish pink color indicated that these are gram negative (Fig. 4).

\section{Biovar differentiation}

The biovar of $R$. solanacearum isolates were identified by utilizaion of disaccharides and sugar alcohols. The result of the biovar test showed that, all six isolates of $R$. solanacearum oxidized disaccharides 
(Sucrose, lactose, and maltose) and sugar alcohols (mannitol, sorbitol and dulcitol) within 7-10 days (Table 4). The oxidation reaction was indicated by the change of color. The isolates 3 and 6 changed the color to yellow from blue indicating the oxidation of sugars and alcohol and hence they belong to biovar-III. Further Isolate-1, Isolate-2 Isolate4 and isolate-5 utilized only sugar but not sugar alcohol and hence they belonged to biovar-II (Table 4 and Fig. 10). On the other hand, all the control plates of different sugars and sugar alcohols remain unchanged.

\section{Bacterial genomic DNA isolation and quantification}

Genomic DNA was extracted from the six isolates of $R$. solanacearum and quantified (Fig. 11) by nanodrop. The maximum DNA amount was observed in isolate-2 (1455 $\mathrm{ng} / \mu \mathrm{l})$ followed by isolate-3 (1399 $\mathrm{ng} / \mu \mathrm{l})$, isolate-4 (1390 $\mathrm{ng} / \mu \mathrm{l})$, isolate-5 $(1220 \mathrm{ng} / \mu \mathrm{l})$, isolate-6(1219 $\mathrm{ng} / \mu \mathrm{l})$ and isolate-1 (1207 ng/ $\mu \mathrm{l})$. Purity of DNA was observed by A260/280 ratio. The A260/280 ratio was found to nearer to 1.8 in all isolates of $R$. solanacearum.

\section{Molecular characterization of six isolates of Ralstonia solanacearum}

Isolates of $R$. solanacearum were characterized by ten DNA Markers (Table 4 and 5). The genomic DNA was subjected to PCR, the PCR amplification resulted in a 300 base pair (bp) product (Fig. 12) for (OLI1 and Y2) and 292 bp product (Fig. 13) for (Y1 and Y2) from all six isolates of $R$. solanacearum.

OLI1 and Y2 primer derived from 16S rDNA sequence of $R$. solanacearum and Y1 and Y2 derived from $16 \mathrm{~S}$ rRNA. This result confirmed that all bacterial isolates were $R$. solanacearum.

\section{Phylotype determination}

A phylotype-specific multiplex PCR (PmxPCR) was performed to determine the phylotype affiliation of all strains. A set of four phylotype-specific forward primers (Nmult:21:1F: Nmult:21:2F: Nmult:22:InF: and Nmult:23:AF: ), with a unique conserved reverse primer (Nmult:22:RR:) and $R$. solanacearum specific primers $(759 \mathrm{R}$ and 760F) (Table 5), these primers targeted in the $16 \mathrm{~S}-23 \mathrm{~S}$ intergenic spacer region (internal transcribed spacer). The Pmx-PCR of six isolates of $R$. solanacearum yielded 144-bp amplicon and 280 bp amplicon (Fig. 14). It revealed that all isolates were $R$. solanacearum and belonged to phylotype I.

\section{Isolation and characterization of six bacterial isolates}

$R$. solanacearum was isolated from infected samples of six locations of Karnataka and culturing was achieved through streaking a bacterial suspension (in water) onto a selective medium, tetrazolium chloride (TZC) agar plates (Elphinstone et al., 1998; Wenneker et al., 1999; Chandrashekara et al., 2012). It produced irregular-shaped white colonies with pink centers, resembling those of $R$. solanacearum. All the isolates grown on TZC medium had similar characteristics with minor variations which are depicted in (Table. 1). This result also supported by Kelman (1954), Klement (1990), Rahman et al., (2010), Chandrashekara et al., (2012), Popoola et al., (2015). Kelman (1954): used triphenyltetrazolium chloride (TZC) medium to distinguish $R$. solanacearum among other bacteria during isolation. Also, when TZC medium was used with $R$. solanacearum, has showed the difference between avirulent colonies that look dark red from the fluidal virulent that are white with pink center, here also we found similar differences between virulent and avirulent colony appearance (Fig. 2). 
Table.1 Collection of six bacterial isolates from Karnataka

\begin{tabular}{|c|c|c|c|c|}
\hline Sl.No. & Isolates & Source & Crop & Morphology on TZC media \\
\hline 1 & Isolates 1 & IIHR, Bangalore & Tomato & $\begin{array}{l}\text { Irregular with smooth margin, convex, creamish } \\
\text { colony with light pink centre. }\end{array}$ \\
\hline 2 & Isolates 2 & IIHR, Bangalore & Brinjal & $\begin{array}{l}\text { Spherical, convex, pink centered with cream } \\
\text { border colonies }\end{array}$ \\
\hline 3 & Isolates 3 & Hebbal, Bangalore & Tomato & $\begin{array}{l}\text { Spherical, dull white colonies with pink centre, } \\
\text { convex }\end{array}$ \\
\hline 4 & Isolates 4 & $\begin{array}{l}\text { GKVK, Farm, UAS, } \\
\text { Bangalore }\end{array}$ & Tomato & Spherical, dull white colonies pink at centre \\
\hline 5 & Isolates 5 & Karavali, Karnataka & Tomato & Spherical pink colored colonies, convex \\
\hline 6 & Isolates 6 & $\begin{array}{l}\text { GKVK, Farm, UAS, } \\
\text { Bangalore }\end{array}$ & Brinjal & $\begin{array}{l}\text { Irregular, smooth margin, pink centered with } \\
\text { cream border colonies, }\end{array}$ \\
\hline
\end{tabular}

Table.2 Number of colony found at six dilution of six isolates of $R$. solanacearum

\begin{tabular}{|c|c|c|c|c|c|c|c|c|c|c|c|c|c|c|}
\hline & \multicolumn{2}{|l|}{$10^{0}$} & \multicolumn{2}{|l|}{$10^{-1}$} & \multicolumn{2}{|l|}{$10^{-2}$} & \multicolumn{2}{|l|}{$10^{-3}$} & \multicolumn{2}{|l|}{$10^{-4}$} & \multicolumn{2}{|l|}{$10^{-5}$} & \multicolumn{2}{|l|}{$10^{-6}$} \\
\hline & OD & $\mathrm{CFU}$ & OD & $\mathrm{CFU}$ & OD & CFU & OD & $\mathrm{CFU}$ & OD & $\mathrm{CFU}$ & OD & $\mathrm{CFU}$ & OD & $\mathrm{CFU}$ \\
\hline $\begin{array}{l}\text { Isolate } \\
1\end{array}$ & 1.76 & Uncountable & 0.82 & 120 & 0.64 & 41 & 0.51 & 29 & 0.43 & 3 & 0.36 & 3 & 0.10 & 0 \\
\hline $\begin{array}{l}\text { Isolate } \\
2\end{array}$ & 1.75 & Uncountable & 0.90 & Uncountable & 0.74 & 80 & 0.65 & 75 & 0.36 & 35 & 0.23 & 40 & 0.08 & 8 \\
\hline $\begin{array}{l}\text { Isolate } \\
3\end{array}$ & 1.05 & Uncountable & 0.90 & 180 & 0.77 & 90 & 0.52 & 73 & 0.25 & 59 & 0.13 & 30 & 0.06 & 28 \\
\hline $\begin{array}{l}\text { Isolate } \\
4\end{array}$ & 1.89 & Uncountable & 0.90 & Uncountable & 0.78 & 150 & 0.54 & 70 & 0.30 & 35 & 0.23 & 33 & 0.14 & 25 \\
\hline $\begin{array}{l}\text { Isolate } \\
5\end{array}$ & 2.23 & Uncountable & 0.99 & Uncountable & 0.96 & Uncountable & 0.75 & 70 & 0.61 & 47 & 0.34 & 27 & 0.27 & 21 \\
\hline $\begin{array}{l}\text { Isolate } \\
6\end{array}$ & 2.22 & Uncountable & 0.99 & Uncountable & 0.99 & Uncountable & 0.71 & 70 & 0.59 & 61 & 0.38 & 45 & 0.14 & 21 \\
\hline
\end{tabular}

OD- optical density, CFU- Colony Forming Unit

Table.3 Race of $R$. solanacearum by host range

\begin{tabular}{|l|l|l|l|l|}
\hline Sl.NO. & Race & Natural host & Geographical distribution & Biovars \\
\hline 1 & 1 & $\begin{array}{l}\text { Wide variety: Ginger, olive, chili pepper, } \\
\text { peanut, Solanum spp., and tobacco }\end{array}$ & $\begin{array}{l}\text { Asia, Africa, Australia, North } \\
\text { America, and South America }\end{array}$ & $1,3,4$ \\
\hline 2 & 2 & $\begin{array}{l}\text { Musa spp. (banana and plantain), peanut, } \\
\text { Heliconia, and tomato }\end{array}$ & $\begin{array}{l}\text { Caribbean, Asia, Central } \\
\text { America, South America, and } \\
\text { Hawaii }\end{array}$ & 1 \\
\hline 3 & 3 & Solanaceous, and Pelargonium spp. (Geranium) & $\begin{array}{l}\text { Worldwide (except Canada and } \\
\text { United States) }\end{array}$ & 2 \\
\hline 4 & 4 & Ginger & Australia, India, Asia, and Hawaii & 3,4 \\
\hline 5 & 5 & Morus spp. (Mulberry) & 5 \\
\hline
\end{tabular}


Table.4 Differentiation of $R$. solanacearum strains into biovars based on the ability to utilize disaccharides and oxidize hexose alcohols producing acid when positive $(+)$

\begin{tabular}{|l|c|c|c|c|c|}
\hline Biochemical test & \multicolumn{5}{|c|}{ Biovar } \\
\hline (Utilization of) & 1 & 2 & 3 & 4 & 5 \\
\hline Cellobiose & - & + & + & - & + \\
\hline Lactose & - & + & + & - & + \\
\hline Maltose & - & + & + & + & + \\
\hline Oxidation of & - & - & + & + & + \\
\hline Dulcitol & - & - & + & + & + \\
\hline Mannitol & - & - & + & + & + \\
\hline Sorbitol & - & & & + & + \\
\hline
\end{tabular}

Table.5 List of 16S Rrna primer name and sequence information

\begin{tabular}{|l|l|l|l|}
\hline SL.N. & universal primers & Sequence of the primer & \\
\hline 1 & OLI1 & 5'GGGGGTAGCTTGCTACCTGCC3' & \multirow{2}{*}{ 300 bp } \\
\hline 2 & Y2 & 5'CCCACTGCTGCCTCCCGTAGGAGT3') & \\
\hline 3 & Y1 & 5'TGGCTCAGAACGAACGCGGCGGC3' & \multirow{2}{*}{$292 \mathrm{bp}$} \\
\hline 4 & Y2 & 5'CCCACTGCTGCCTCCCGTAGGAGT3') & \\
\hline
\end{tabular}

Table.6 List of primers used for multiplex PCR (determination of phylotype)

\begin{tabular}{|l|l|l|l|l|}
\hline $\begin{array}{l}\text { SL.N } \\
\text { O. }\end{array}$ & Primer & Primer sequence & $\begin{array}{l}\text { Expected } \\
\text { band size }\end{array}$ & Remarks \\
\hline 1 & Nmult:21:1F & 5'-CGTTGATGAGGCGCGCAATTT-3' & $144 \mathrm{bp}$ & $\begin{array}{l}\text { Phylotype I } \\
\text { (Asiaticum) }\end{array}$ \\
\hline 2 & Nmult:21:2F & 5'-AAGTTA TGGACGGTGGAAGTC-3' & $372 \mathrm{bp}$ & $\begin{array}{l}\text { Phylotype II } \\
\text { (Americanum) }\end{array}$ \\
\hline 3 & Nmult:22:InF & 5'-ATTGCCAAGACGAGAGAAGTA-3 & $213 \mathrm{bp}$ & $\begin{array}{l}\text { Phylotype IV } \\
\text { (Tropical) }\end{array}$ \\
\hline 4 & Nmult:23:AF & 5'-ATTACGAGAGCAATC GAAAGATT-3' & $91 \mathrm{bp}$ & $\begin{array}{l}\text { Phylotype II } \\
\text { (African) }\end{array}$ \\
\hline 5 & Nmult:22:RR & 5'-TCGCTTGACCCTATAACGAGTA-3 & $\begin{array}{l}\text { Amorce reverse } \\
\text { unique }\end{array}$ \\
\hline 6 & $759 \mathrm{R}$ & 5'-GTCGCCGTCAACTCACTTTCC-3' & $280 \mathrm{bp}$ & $\begin{array}{l}\text { Universal } \\
\text { R.solanacearum } \\
\text { specific primers }\end{array}$ \\
\hline 7 & $760 \mathrm{~F}$ & 5'-GTCGCCGTCAGCAATGCGGAATCG-3' & & \\
\hline
\end{tabular}


Fig.1 Colonies morphology of $R$. solanacearum on TZC Media
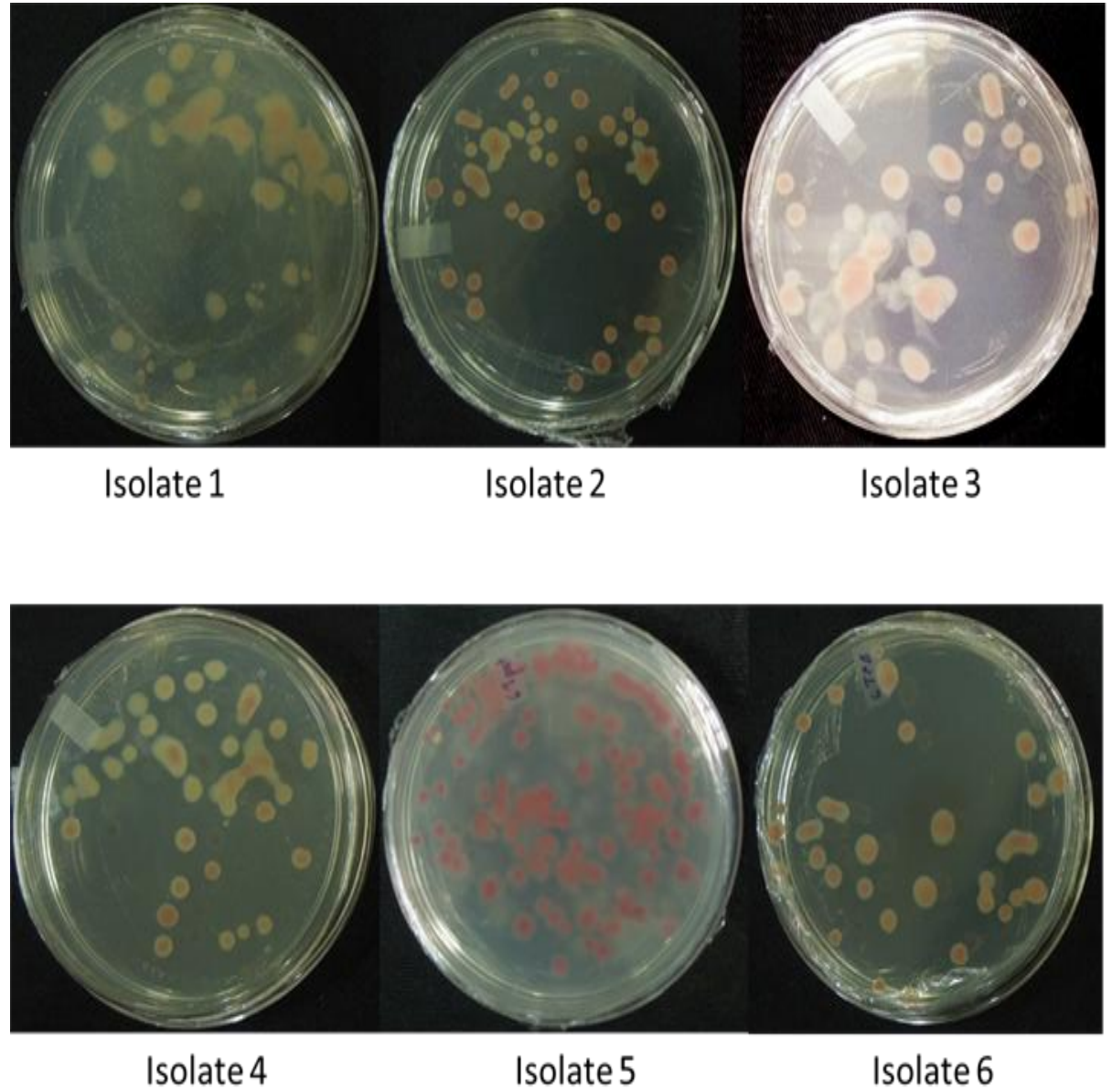

Fig.2 Plate showing virulent/nonvirulent strains of $R$. solanacearum

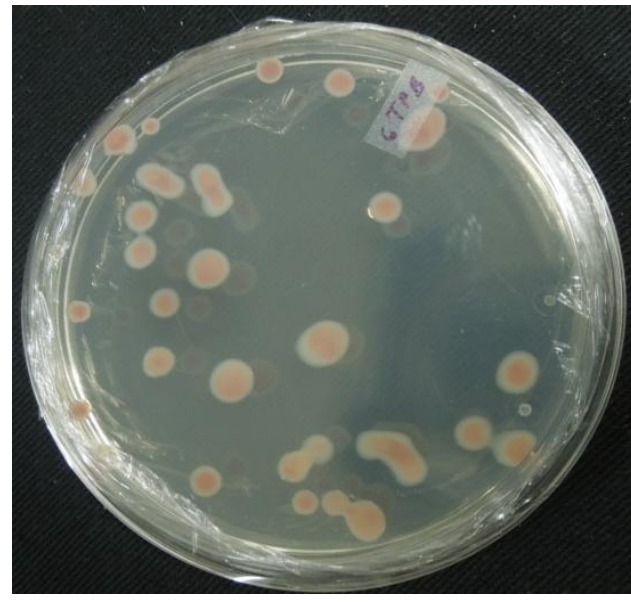

a. Virulent

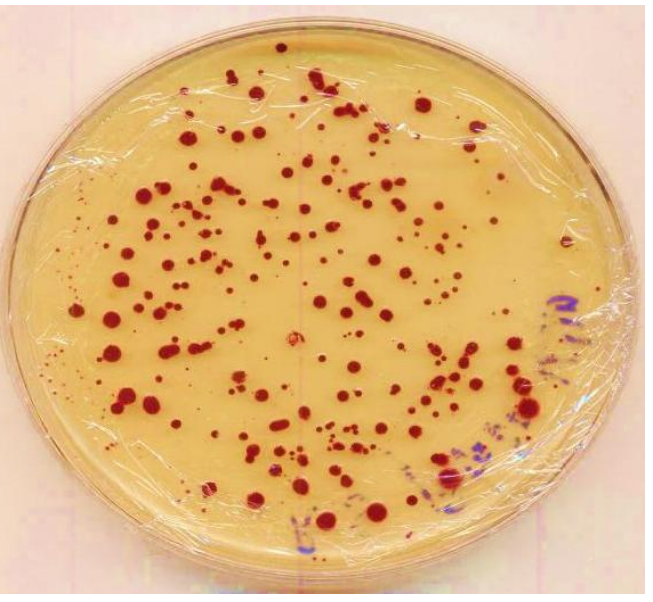

b. nonvirulent 
Fig.3 The CFU (colony forming units) count at different dilutions of isolates of $R$. solanacearum

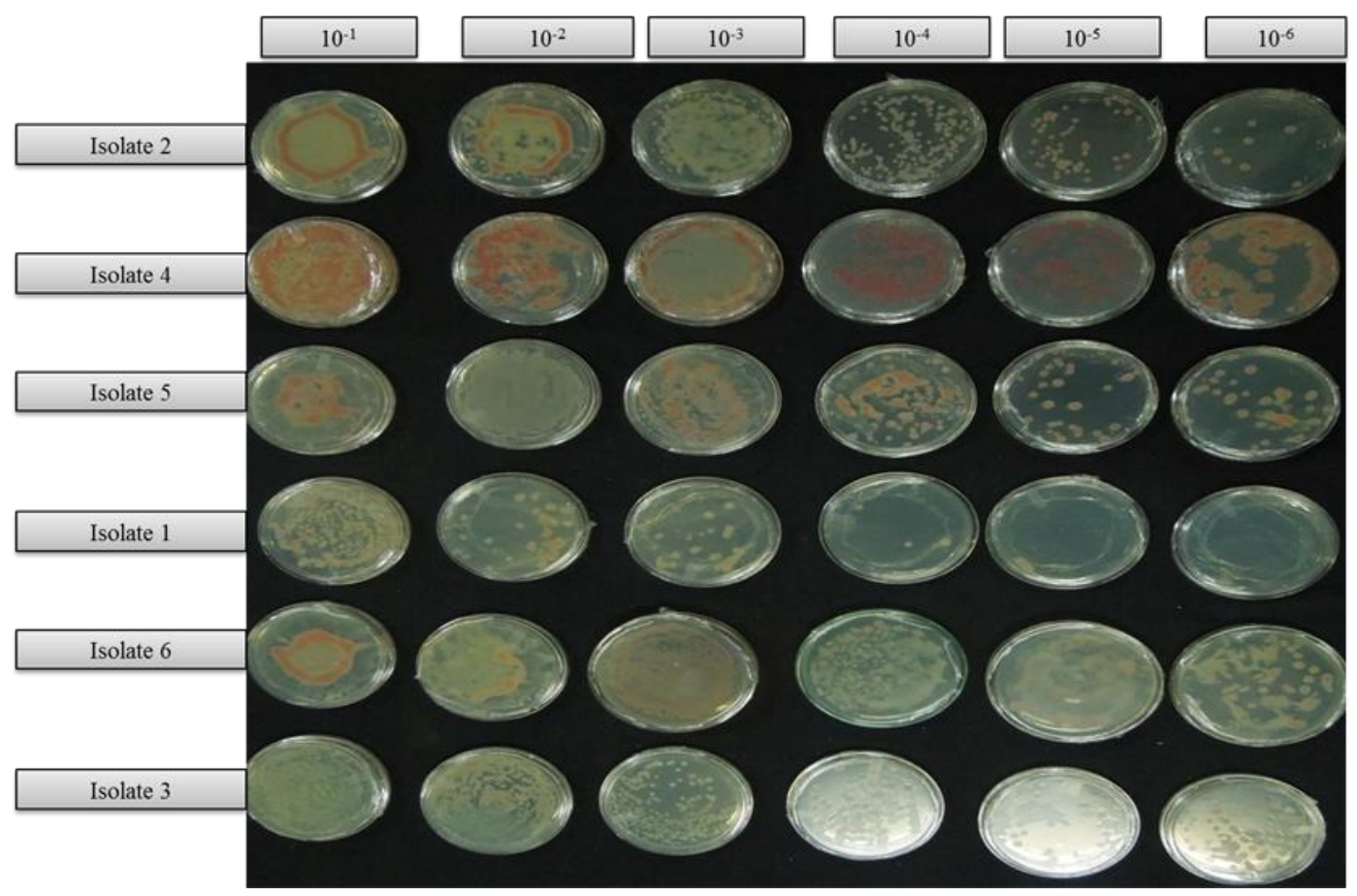

Fig.4 Gram's stain response of the six isolates of $R$. solanacearum

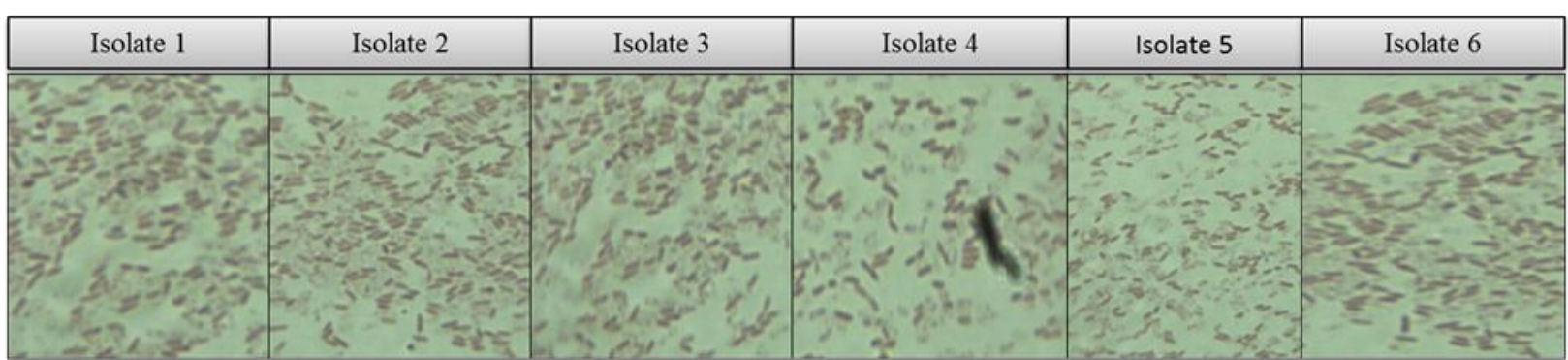

Fig.5 Bacterial wilt symptoms of six isolates in Capsicum annum

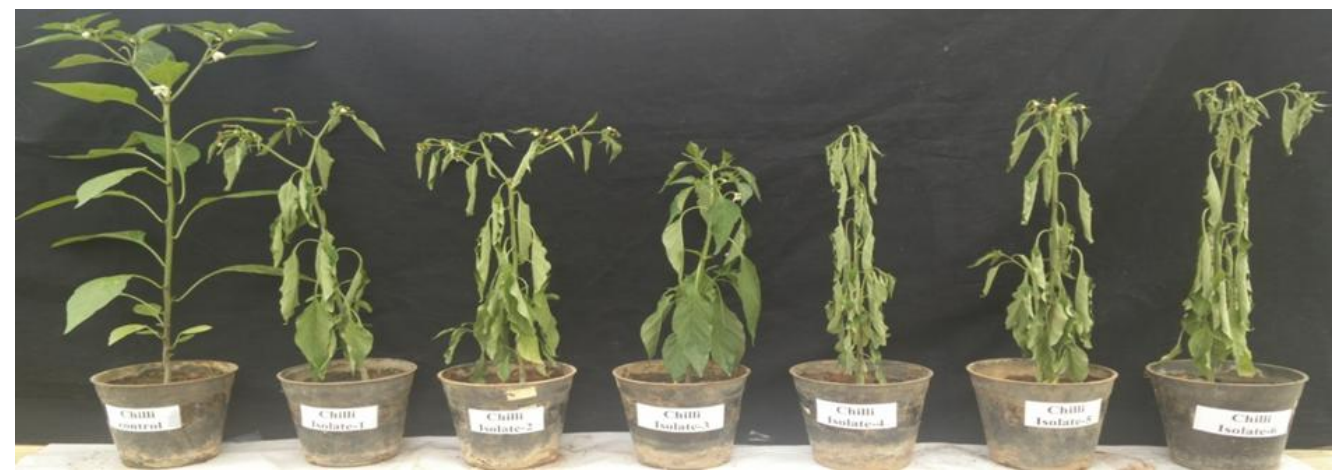


Fig.6 Bacterial wilt symptoms of six isolates in Solanum melongena

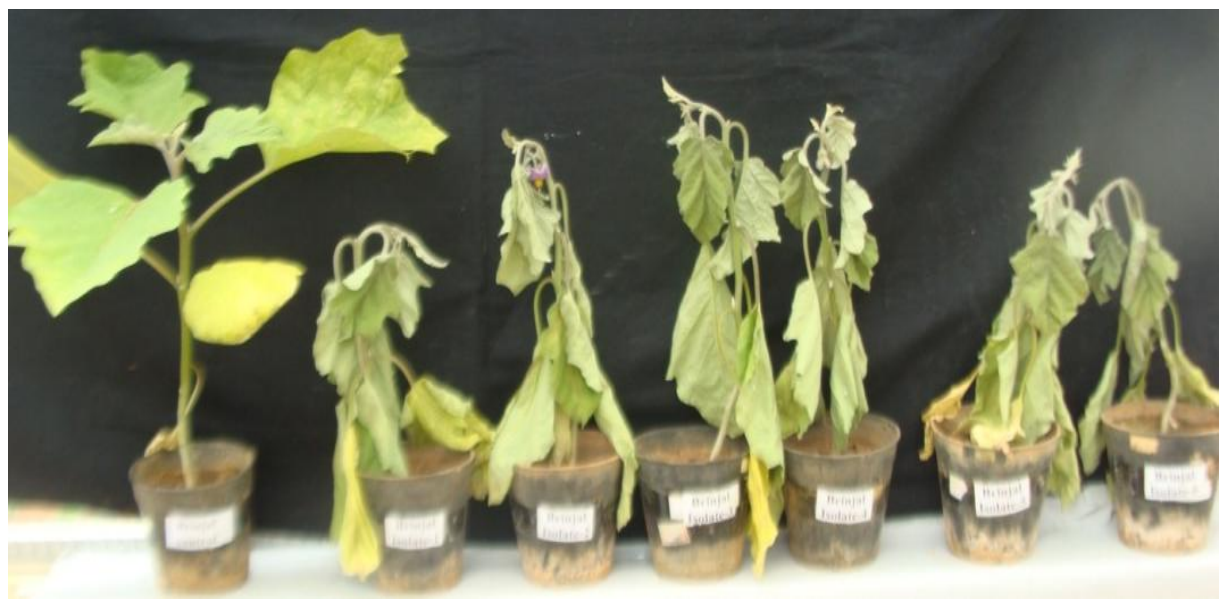

Fig.7 Bacterial wilt symptoms of six isolates in Solanum lycopersicum

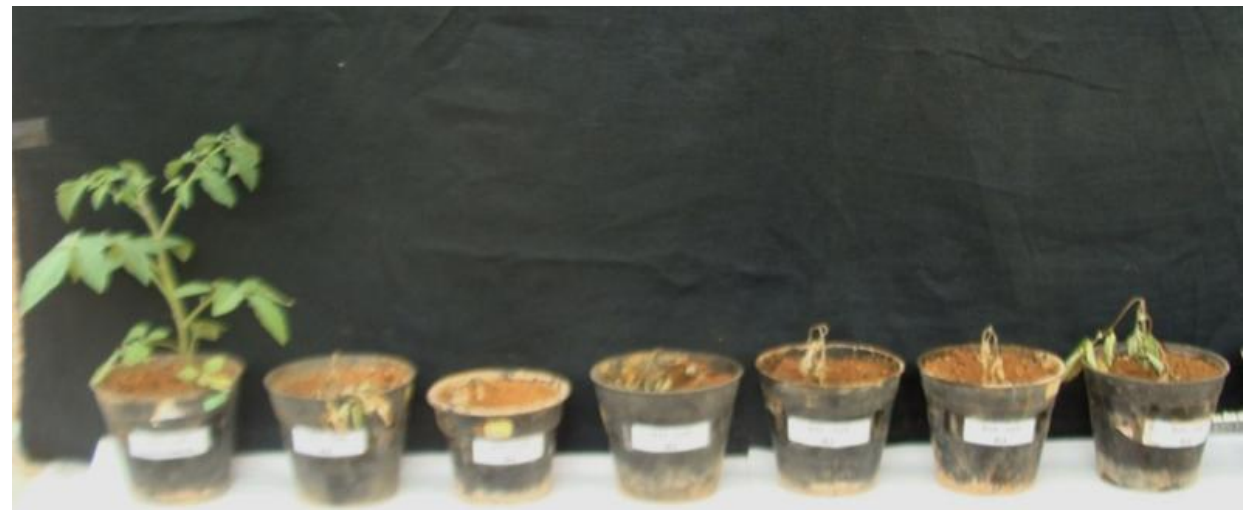

Fig.8 Bacterial wilt symptoms of six isolates in Morus alba

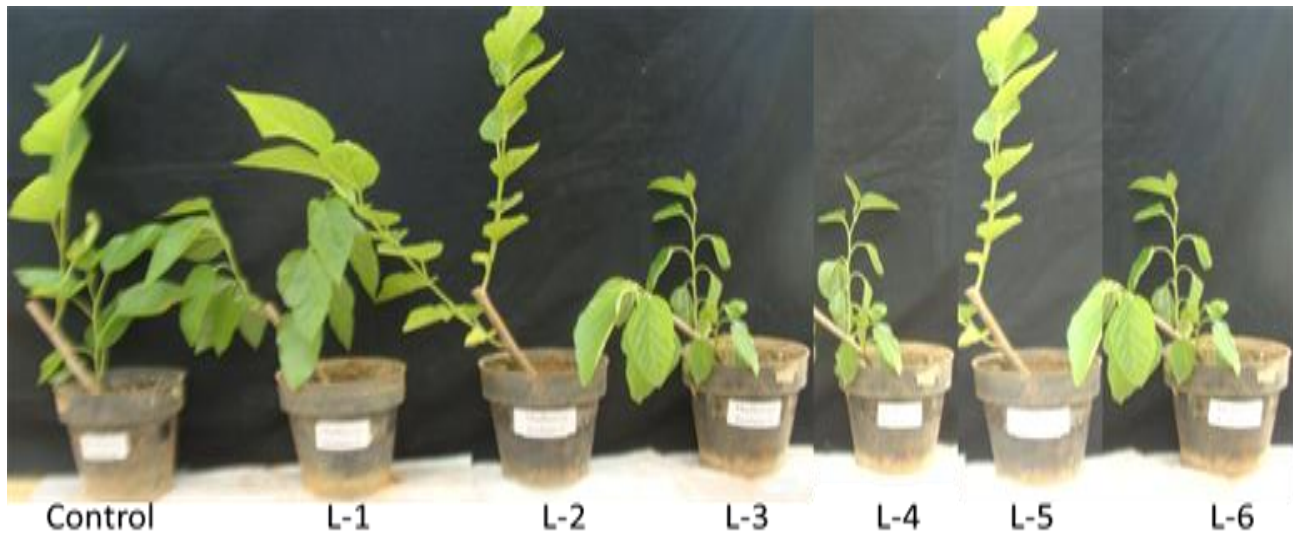


Fig.9 Bacterial streaming test

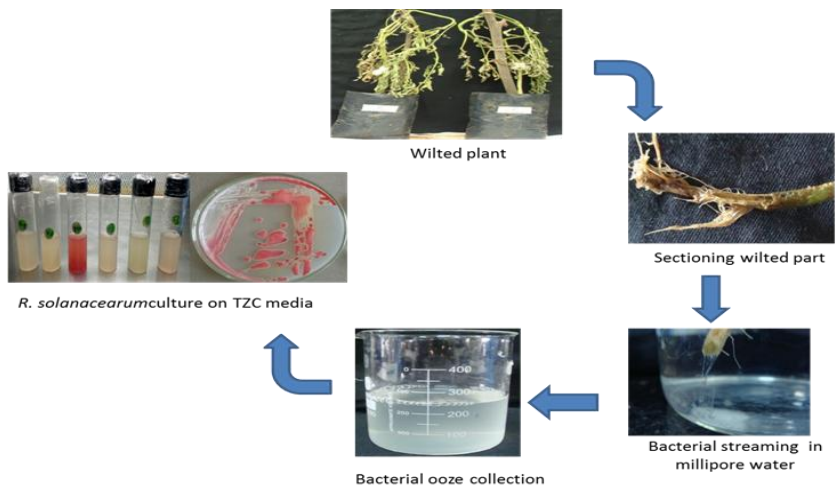

Fig.10 Biovar test showing positive (+ve) yellow color and negative (-ve) green color reaction indicating the utilization of sugar and alcohol by Ralstonia solanacearum isolates in microtitre plate

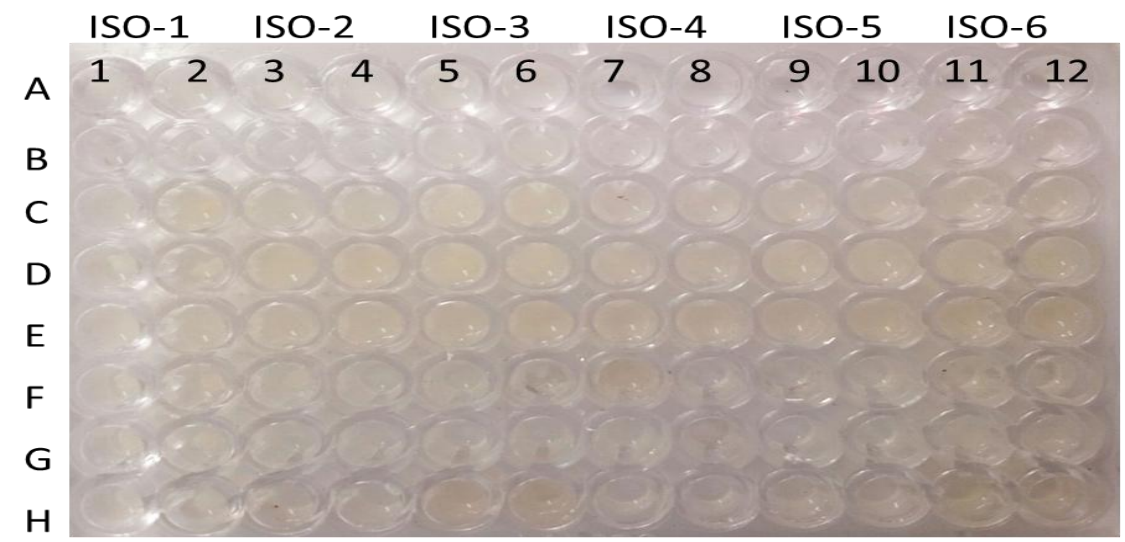

wells1,2- Isolate(1) 3,4- Isolate(2) 5,6-Isolate-3 7,8-Isolate(4) 9,10-Isolate(5) 11,12-Isolate(6) A- without carbohydrte, B-without $R$. solanacearum, C-Lactose, D-Maltose, E-Cellobiose, F-Mannitol, G-Sorbitol, H-Dulcitol

Fig.11 Agarose gel profile of total genomic DNA of Ralstonia solanacearum

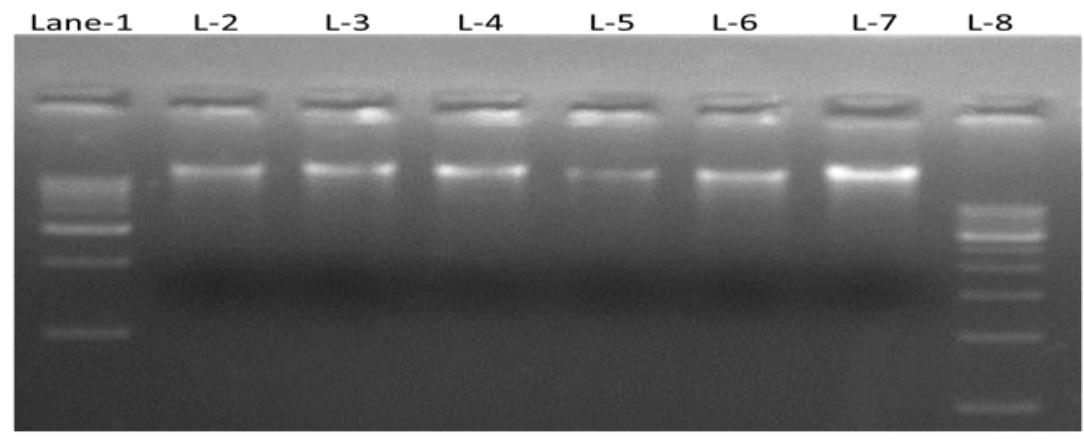

Lane1-Ladder 5kb, Lane8-Ladder1kb, Lane(2-7)- Isolates 
Fig.12 Electrophoretic analysis of PCR amplified DNA from six isolates of Ralstonia solanacearum using the primer Y1 and Y2

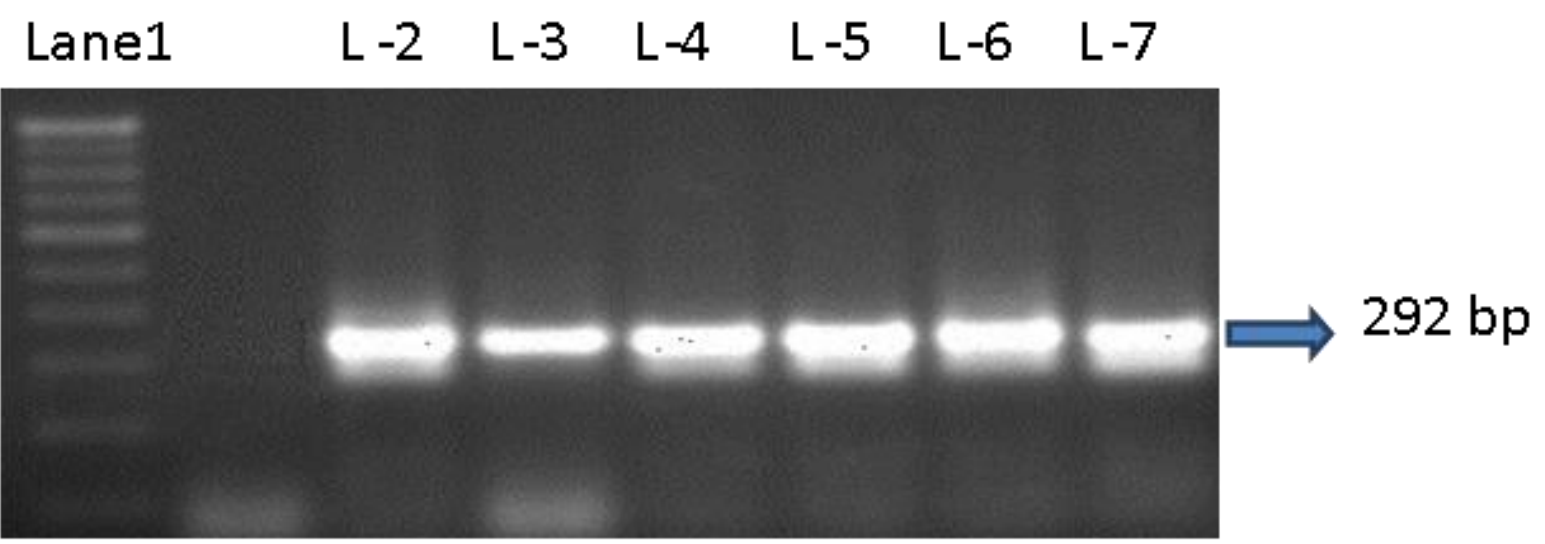

Lane1-1kb ladder, lane(2-7)-isolates

Fig.13 Electrophoretic analysis of PCR amplified DNA from six isolates of Ralstonia solanacearum using the primer OLI1 \&Y

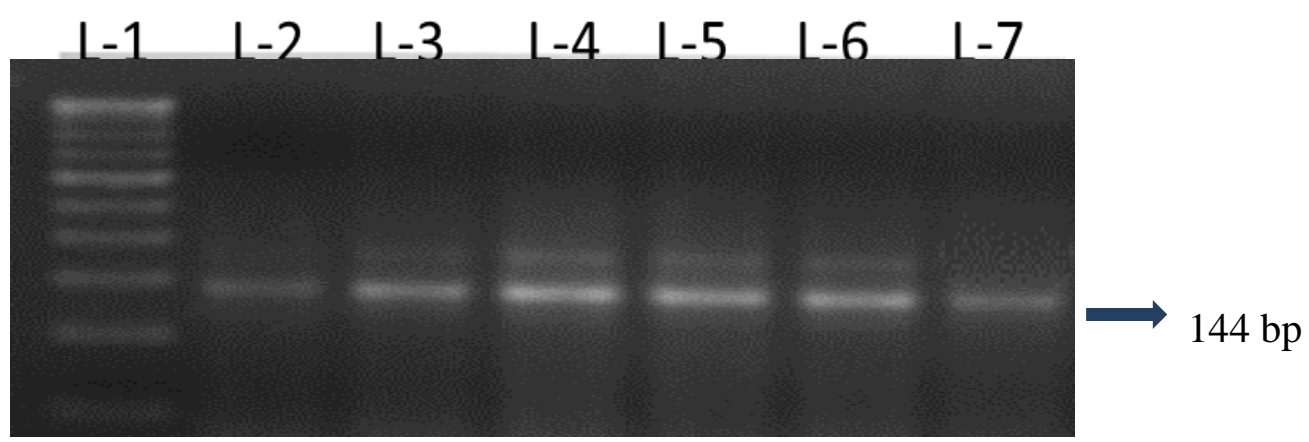

Lane1 -ladder, Lane(2-7)- isolates

Fig.14 PMX-PCR using a phylotype specific primer showing PCR product 280bp amplicon for all isolates and 144bp phylotype 1

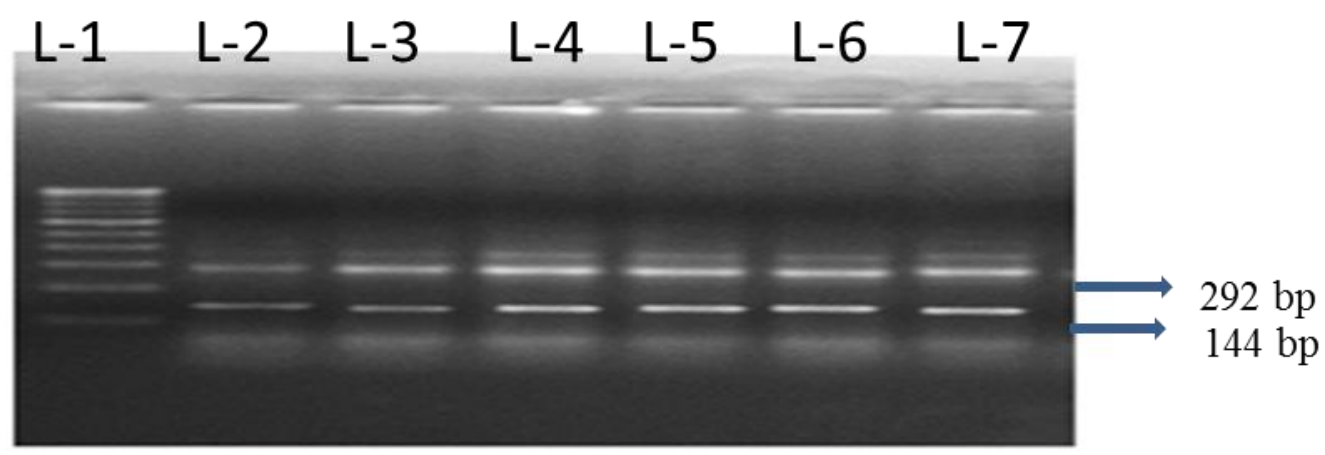

Lane1- ladder $1 \mathrm{~kb}$, lane(2-7)- isolates 
The number of colony forming unit (cfu) observed at six dilutions of all isolates of Ralstonia solanacearum. In all isolates the colony forming units were uncountable at zero dilution. This result in conformity with Adams et al., (2014), Kwiatkowski et al., (2015), Mensah and Twumasi (2016), Hendry et al., (2014), even they could find 40 plates out of 1440 were having uncountable colonies due to spreading of the colonies. It was observed that the plates were having uncountable colonies at zero dilution because of more number of colonies and due to spreading. At sixth dilution, the maximum cfu were recorded in isolate-3(28), isolate-4(25), isolate-5(21), isolate-6(21), isolate-2(8) and no colony forming unit (cfu) observed in isolate-1(0).

The virulent and avirulent isolates of $R$. solanacearum were differentiated by Kelman Tetrazolium Chloride (TZC) agar test. Results of this test showed that all isolates of $R$. solanacearum collected from different growing areas produced pink or light red color colonies with characteristic red centre and whitish margin on TZC medium. This indicates that all $R$. solanacearum isolates were virulent. Kelman (1954) reported that avirulent colony types of $R$. solanacearum could be easily differentiated by the pigmentation from the wild virulent types. $R$. solanacearum developed two types of colonies on tetrazolium chloride (TZC) medium on which virulent colonies appear as white with pink centre and non-virulent colonies appear as small off-white colonies. On this medium, typical bacterial colonies appear fluidal, irregular in shape, and white with pink centres after 2 to 5 days incubation at $28^{\circ} \mathrm{C}$ as reported by Champoiseau (2008). $R$. solanacearum produced fluidal colonies with pink or light red color on TZC media after 24 hours of inoculation as reported previously by Rahman et al., (2010), Ahmed et al., (2013).
Denny and Hayward (2001) identified race of $R$. solanacearum by host specificity with infiltration/inoculation methodology used as simple and quick means of determining the race of any particular virulent isolate of this pathogen (Lozano and Sequiera, 1970; Lemessa and Zeller, 2007). In the present study, four isolates belonged to Race 3 while two belonged to Race 1 . The findings of the present study are also supported by Buddenhagen et al., (1962), Ahmed et al., (2013), Popoola et al., (2015). R. solanacearum Race 1 strains infect tobacco, tomato, and many other solanaceous crops, and certain diploid bananas. Race 3 causes wilting in potato, tomato and rarely other solanaceous plants. Race 2 is known to infect triploid banana (Musa spp.) and Heliconia spp., while Race 4 infects mulberry (He et al., 1983; OEPP/EPPO 2004). He et al., (1983) reported Race 5 on Mulberry from China. Therefore, five races have been described so far, but they differ in host range, geographical distribution and ability to survive under different environmental conditions (French, 1986). Race 3 is highly virulent on potatoes, tomatoes and other solanaceous crops (Hudelson et al., 2002; Janse et al., 2004). Its temperature optimum is lower than that of other races and this might partly its preponderance in temperate regions of the World and places like Bangalore (Karnataka).

To diagnose the presence of Ralstonia Streaming test was performed. Popoola et al., (2015) observed similar results. The Gram's staining reaction was performed using crystal violet as described by Schaad (1980). The microscopic results showed that all the isolates of $R$. solanacearum did not retain violet colour i.e. the isolates retained counter stain (pink colour). Therefore, all isolates of $R$. solanacearum representing each group are gram negative and straight or curved, rod shaped. These results are in conformity with the findings of Suslow et al., (1982), 
Chaudhry and Rashid (2011) and Ahmed et al., (2013), Popoola et al., (2015).

Biovar characterization showed that most of the $R$. solanacearum isolates oxidized disaccharides (sucrose, lactose, and maltose) and sugar alcohols (mannitol, sorbitol and dulcitol). The oxidation reaction was indicated by the change of color. In present study, isolate-3 and isolate-6 of $R$. solanacearum belong to biovar III whereas isolate-1, isolate-2, isolate-4 and isolate- 5 belonged to biovar-2 (Table 3 and Fig. 10). The differentiation of biovars of $R$. solanacearum based on the utilization of carbohydrates was reported previously by Hayward (1964), He et al., (1983), Kumar et al., (1993), Chaudhry and Rashid (2011), Ahmed et al., (2013) and Popoolaet al., (2015). They also observed that, biovar III oxidizes both disaccharides and hexose alcohols, biovar II oxidizes only disaccharides whereas Biovar I oxidizes hexose alcohols only, and biovar IV oxidizes only alcohols.

Genomic DNA was extracted from all six isolates of $R$. solanacearum and subjected to PCR by $R$. solanacearum specific primers. Partial sequences of $16 \mathrm{~S}$ rDNA and 16S rRNA genes are excellent targets for identification of bacteria at the species level as they are species-specific and available in multiple copies in microbial genome. The corresponding specific rDNA and rRNA sequences have been used as targets for PCR amplification (Woese, 1987).

In this study, the PCR amplicon resulted in a $\sim 300$ base pair (bp) product for (OLI1\& Y2) and 292 bp products for (Y1 \& Y2) from all isolates of $R$. solanacearum. This result confirmed that all the isolates are $R$. solanacearum. It was supported by earlier results of Seal, (1993), Chandrashekara (2012) and Chandrashekara (2012) for $R$. solanacearum.
For phylotype identification, a set of four phylotype-specific forward primers (Nmult:21:1F: Nmult:21:2F: Nmult:22:InF: and Nmult:23:AF:), with a unique and conserved reverse primer (Nmult:22:RR:) and set of $R$. solanacearum specific primers (759R and $760 \mathrm{~F}$ ) as described (Fegan and Prior 2005; Prior and Fegan 2005) was used. This primers sequence was targeted to the 16S-23S intergenic spacer region (internal transcribed spacer).

The results of Pmx-PCR of six isolates of $R$. solanacearum were 144-bp amplicon and 280 bp amplicon. It revealed that all isolates were $R$. solanacearum and belonged to phylotype I. These results were confirmed by Fegan and Prior 2005; Prior and Fegan 2005; Wang et al., (2013); Popoola etal., (2015) and Vanitha et al., (2014).

In conclusion the goal of this research was to collect and characterize the isolates from bacterial prone areas of Karnataka and characterization. In this study, we collected six isolates were collected and characterized as Biovar-2, 3 on the basis of ability to utilize disaccharides (Sucrose, lactose, and maltose) and sugar alcohols (manitol, sorbitol and dulcitol), Race 1, 3 were identified based on their ability to infect different hosts we could class these races as phylotype I based on the ITS sequences of six $R$. solanacearum strains.

\section{Acknowledgement}

We thank Department of Biotechnology, Government of India, for providing financial assistance for this research, University Grants Commission, Government of India for providing fellowship to pursue $\mathrm{Ph}$. D. degree and University of Agricultural Science, Bangalore for providing the facilities. Also, the co-author is thankful to the Department of Plant Physiology, UAS, Bengaluru and DST INSPIRE for providing the financial. 


\section{References}

Ahmed, N.N., Md. Rashidul Islam, MD., Hossain, M.A., Meah, M.B. and Hossain, M.M. 2013. Determination of Races and Biovars of Ralstonia solanacearum Causing Bacterial Wilt Disease of Potato. JAS, Vol. 5, No. 6; 86-93.

Aragaki, M. and Quinon, V.L. 1965. Bacterial wilt of ornamental gingers (Hedychium spp.) caused by Pseudomanas solanacearum. Plant Dis., 49: 378-379.

Begum, N. 2005. Isolation and characterization of $R$. solanacearum (smith) yabuuchi, the causal organism of bacterial wilt in tomatoes, Rawalpindi, Pakistan, PMASArid Agriculture University, M.Sc. Hons) thesis.

Buddenhagen, I., Sequeira, L., Kelman, A. 1962. Designation of races in Pseudomonas solanacearum. Phytopathol., 52: 726.

Champoiseau, G. 2008. Ralstonia solanacearum race 3 biovar 2: detection, exclusion and analysis of a Select Agent Educational modules. The United States Department of Agriculture -National Research Initiative Program (2007-2010).

Chandrashekara, K.N. and Prasannakumar M.K. 2010. New Host Plants For Ralstonia solanacearum from India, News Dis. Reports, 22-6.

Chandrashekara, K.N., M.K. Prasannakumar, M. Deepa and A. Vani. 2012. A rapid, sensitive and reliable method for detecting Ralstonia solanacearum using fta (whatman) card. J. Plant Pathol., 94: 219-221.

Chandrashekara, K.N., Prasannakumar M.K., Deepa, M. and A. Vani, A., Abdul Nazir, A., Khan, A. 2012. Prevalence of Races and Biotypes of Ralstonia solanacearum In India. J. Plant Prot., 51(1): 53-58.

Chaudhry, Z. and Rashid, H. 2011. Isolation and Characterization of Ralstonia solanacearum from Infected Tomato Plants of Soan Skesar Valley of Punjab. Pak. J. Bot., 43(6): 2979-2985.

Cook, D, Elizabeth, B. and Sequeira, L. 1989. Genetic diversity of Pseudomonas solanacearum: detection of restriction fragment length polymorphisms with DNA probes that specify virulence and hypersensitive response. Mol PlantMicrobe Interact, 2: 113-121.

Denny, T.P., \& Hayward, A.C. 2001. Gramnegative bacteria: Ralstonia. In N. W. Schaad, J. B. Jones, \& W. Chun (Eds.), Laboratory guide for identification of plant pathogenic bacteria (pp. 151-174, 3rd edn. APS Press, St. Paul, M.N.

Dharmatti, P.R., Patil, R.V., Revenappa and Mannikeri, I.M. 2009. High yielding and bacterial wilt resistant tomato hybrids. Karnataka J. Agric. Sci., 22(1): 158-160.

Dildar Ahmed, Saman Zara and Hira Baig. 2013. In vitro analysis of antioxidant activities of oxalis corniculatalinn. fractions in various solvents. Afr. $J$. Tradit. Complement Altern. Med., 10(1): 158-165.

Elphinstone, J.G, H.M. Stanford and D.E. Stead. 1998. Detection of Ralstonia solanacearum in potato tubers, Solanum dulcamara, and associated irrigation water. In: Bacterial Wilt Disease: Molecular and Ecological Aspects (Eds.): P. Prior, Allen C \&Elphinstone J), Springer Verlag, Berlin (DE):133139

Fegan, M. and Prior, P. 2005. How complex is the Ralstonia solanacearum species complex? Allen C., Prior, P. and Hayward A. C. ed). Bacterial wilt disease and the Ralstonia solanacearum species complex.APS Press. pp. 449461.

French, E.R. 1986. Interaction between isolates of Pseudomonas solanacearum its hosts and the environment. Persley, G. L. ed). In: Bacterial wilt disease in Asia and the South Pacific. Proceedings of an International workshop held at PCARD, 
Los Banos, The Philippines. pp. 99-104. Gillings, M., Fahy, P. and Davies, C. 1993. Restriction analysis of an amplified polygalacturonase gene fragment differentiates strains of the phytopathogenic bacterium Pseudomonas solanacearum. Lett. Appl. Microbiol., 17: 44-48.

Gnanamanickam, S.S. 2006. Plant-Associated Bacteria (edt.) Springer.724 Pp

Hayward, A.C. 1964. Characteristic of Pseudomonas solanacearum. J. Appl. Bact., 27: 265-277.

Hayward, A.C. 1991. Biology and epidemiology of bacterial wilt caused by Pseudomonas solanacearum. Annu. Rev. Phytopathol., 29: 65-87.

He, L.Y., Sequeira, L. and Kelman, A. 1983. Characteristic of Pseudomonas solanacearum from China. Plant Dis., 67: 1357-1361.

Hendry, T.A., Hunter, M.S. and Baltrusa, D.A. 2014. The Facultative Symbiont Rickettsia Protects an Invasive Whitefly against Entomopathogenic Pseudomonas syringae Strains Tory. Appl. Environ. Micro., 617168.doi:10.1128/AEM.0244714Volume 80.

Hudelson, B.D., Williamson, L., Nakaho, K., Allen, C. 2002. $R$. solanacearum race 3, biovar 2 strains isolated from geranium are pathogenic on potato. In: Proceedings of the 3rd International Bacterial Wilt Symposium, Stellenbosh.

Janse, J.D., van den Beld, H.E., Elphistone, J., Simpkins, S., Tjou-Tam-Sin, N.N.A., van Vaerenbergh, J. 2004. Introduction to Europe of Ralstonia solanacearum biovar 2, race 3 in Pelargonium zonale cuttings. J. Plant Pathol., 86: 147-155.

Kelman, A. 1954. The relationship of pathogenicity in Pseudomonas solanacearum to colony appearance on a tetrazolium medium. Phytopathol., 44: 693-695.

Klement, K., Rudolph, K., Sands, D.C. 1990. Methods in Phytobacteriology. Intl Specialized Book Service Inc. Pp 810.
Kumar, A, RA. Malloch, N. Fujita, DA.Smillie, A. Ishihama, R.S. Hayward. 1993. The minus 35-recognition region of Escherichia coli sigma 70 is inessential for initiation of transcription at an "extended minus 10" promoter. J. Mol. Biol., 232: 406.

Kwiatkowski, Lester; Cox, Peter; Halloran, Paul R., Mumby, Peter, J., Wiltshire, Andy, J. 2015. Coral bleaching under unconventional scenarios of climate warming and ocean acidification. In Nat. Clim. Change, DOI 10.1038/nclimate2655

Lemessa, F., Zeller, W. 2007. Screening rhizobacteria for biological control of Ralstonia solanacearum in Ethiopia. Biol. Control, 42: 336-344.

Lozano, J.C. and L. Sequeira. 1970. Differentiation of races of Pseudomonas solanacearum by a leaf infiltration technique. Phytopathol., 60: 833-838.

Mensah, J.K.M. and Twumasi, P. 2016. Use of pineapple waste for single cell protein (SCP) production and the effect of substrate concentration on the yield. $J$. Food Biochem., 1-9 DOI 12478.

OEPP/EPPO. 2004. Diagnostic protocols for regulated pests: Ralstonia solanacearum. OEPP/EPPO Bull., 34: 173-178.

Popoola, C.A. Popoola, J.A. Ayo, O.E. Adedeji, O. 2015. Akinleye Triethanolamine (TEA) as flow improver for heavy crude oils, IOSR JOC, 8, pp. 34-38.

Poussier, S., Vandewalle, P. and Luisetti, J. 1999. Genetic diversity of African and worldwide strains of Ralstonia solanacearum as determined by PCRrestriction fragment length polymorphism analysis of the hrp gene region. Appl. Environ. Microbiol., 65: 2184-2194.

Prior, P., Fegan, M. 2005. Recent developments in the phylogeny and classification of Ralstonia solanacearum. Acta Hortic., 695: 127-136.

Rahman, M.S., Haque, M.F., Ahasan, M..S, Song, H.J. 2010. Indirect enzyme linked 
immunesorvent assay for the diagnosis of Brucellosis in cattle. Korean J. Vet. Serv., 32(2): 113-119.

Schaad, N.W. 1980. Laboratory guide for the identification of plant pathogenic bacteria. Am. Phytopathol. Soc. St. Paul. Minn., 28-45.

Schaad, N.W., Jones, J.B., Chun, W. 2001. Laboratory Guide for Identification of Plant Pathogenic Bacteria.3nd. Ed. APS Press, St. Paul, MN, USA.

Seal, S.E., Jackson, L.A. and Daniels, M.J. 1992. Use of tRNA consensus primers to indicate subgroups of Pseudomonas solanacearumby polymerase chain reaction. Appl. Environ. Microbiol., 58: 3759-3761.

Seal, S.E., Jackson, L.A., Young, J.P.W. and Daniels, M.J. 1993. Differentiation of Pseudomonas solanacearum, Pseudomonas syzygii, Pseudomonas pickettiand the blood disease bacterium by partial $16 \mathrm{~S}$ rRNA sequencing: construction of oligonucleotide primers for sensitive detection by polymerase chain reaction. J. Gen Microbiol., 139: 1587-1594.

Smith, J.J., Offord, L.C., Holderness, M. and Saddler, G.S. 1995. Genetic diversity of Burkholderia solanacearum (synonym Pseudomonas solanacearum) race 3 in Kenya. Appl. Environ. Microbiol., 61: 4263-4268.

Suslow, T.V., M.N. Schroth and M. Isaka.
1982. Application of a rapid method for Gram differentiation of plant pathogenic and saprophytic bacteria without staining. Phytopathol., 72: 9117-918.

Vanitha, Antony Sylvan D'Souza, Vanishri Nayak. 2014. Variations In The Innervations To The Gluteus Maximus Muscle: A Case Report. Ijmrhs, Doi: 10.5958/2319-5886.2014.00424.X

Wang, H., H. Yang, CS. Shivalila, M.M. Dawlaty, A.W. Cheng, F. Zhang, R. Jaenisch. 2013. One-step generation of mice carrying mutations in multiple genes by CRISPR/Cas-mediated genome engineering, Cell, 153 pp. 910918.

Wenneker, M., Verdel, M.S.W., Van Beuningen, A.R., Derks, J.H.J. and Janse, J.D. 1999. Ralstonia (Pseudomonas) solanacearum race 3 (biovar 2) in surface water and natural weed hosts: first report on stinging nettle (Urticadioica. Eur. J. Plant Pathol., 105: 307-315.

Woese, C.R. 1987. Bacterial evolution, Microbiol. Rev., 5: 221-271.

Yabuuchi, E., Kosako, Y. Yano, I. Hotta, H., Nishiuchi, Y. 1995. Transfer of two Burkholderia and an Alcaligenes species to Ralstonia gen. nov.: Proposal of Ralstonia pickettii, Ralstonia solanacearum and Ralstonia eutropha. Microbiol. Immunol., 39: 897-904.

\section{How to cite this article:}

Sujeet Kumar, Kedarnath, N. Hamsaveni, I.B. Rohini, K.T. Rangaswamy, P.H. Ramanjini Gowda and Raghavendra Achari. 2017. Isolation and Characterization of Ralstonia solanacearum Causing Bacterial Wilt of Solanaceae Crops. Int.J.Curr.Microbiol.App.Sci. 6(5): 1173-1190. doi: https://doi.org/10.20546/ijcmas.2017.605.128 